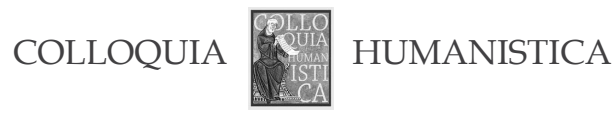

Jolanta Sujecka

Institute of Slavic Studies

Polish Academy of Sciences

Warsaw

\title{
The Continuity and Discontinuity. The Question of Territorialism and Double Identity from the Perspective of 20th Century Macedonia
}

$\mathrm{T}$ he issue of territorialism has spurred considerable multidisciplinary literature (B. Szacka, 1987; A. Kłoskowska, 1993; 1997; A. D. Smith, 1999). Its connection to the question of double identity, as reflected in the title of this paper, is not accidental and therefore, I imagine, requires an explanation (M. Melchior, 1990; 2004). Is not my ambition here to construct sweeping generalizations, the connection between the two issues in the title was dictated rather by my desire to share the knowledge about a corner of Balkan Europe where territorialism and double identity, albeit not yet verbalised as a coherent concept, have long determined, it seems, the way of perceiving one's place in the world. Included implicitly in a number of statements published in the late 19th and throughout the 20th century by representatives of the Macedonian diaspora (Macedonia being the focus of my analysis), the two attitudes towards others, that is towards both the Balkans and the more distant Europe, constituted an integral part of the identity of (certain) Macedonian elites. (I use the term 'Macedonian elites' in its territorial sense to denote the intelligentsia from the territory of Macedonia in the late 19th and the first half of the 20th century.) Coexistence of these two attitudes, i.e. territorialism and double identity, was dependent on the state of the ethnic consciousness of a given group inhabiting Macedonia. It has occurred differently among the Jews from that area than among the Slavs. Among the latter it accompanied emerging ethnic self-identification. The 20th century, and especially its first half, determined their national choices. My presentation is an attempt to decipher the complicated axiological network conditioning the semantics of the term 'a Macedonian' in the 20th century from the point of view of Slavs living in the territory of Macedonia. 


\section{Slavia Orthodoxa - Slavia Balcanica - Slavia Macedonica}

Before the slogan “integral Macedonia” (целокупна Македонија) appeared on the banners of the Ilinden uprising in 1903, the organization which brought it about, known from contemporary Macedonian history books as the Internal Macedonian-Edrine Revolutionary Organization IMRO, originally bore a different name, though only for a short time. At the founding convention, which took place in the small town of Resen in Vardar Macedonia in 1894, the Bulgarian Macedonian-Edrine Revolutionary Committee (БМОРОBMERO) (Бугарски македоно-одрински револуционен комитет), later known as IMRO, formulated its first document, according to which "every Bulgarian without a criminal record regardless of sex" could become a member. Only two years later at the next convention in Thessalonica membership requirements were altered, along with the organization's name, changed into Secret Macedonian-Edirne Revolutionary Organization. According to the Thessalonica declaration of 1896 the aim of the organization was to "unite all dissatisfied groups in Macedonia and the Adrianople district, regardless of nationality, in order to gain, through revolution, unlimited political autonomy for the two districts" (I. Stawowy-Kawka, 2000).

The Thessalonica convention gave birth to the so-called "autonomists" united by the belief in the possibility of preserving territorial unity, verbalized in the slogan "integral Macedonia." The call "Macedonia for Macedonians" became its ethnic motto encompassing all inhabitants of Macedonia regardless of their nationality or creed. Although the organizers of the uprising were Slavs, they also called upon Turks to take arms.

Introduction of the term 'Macedonian' in place of 'Bulgarian' in the late 19 th century was a substantial change to the organization's political aims and went hand in hand with the regional elites' search for the most adequate name for the germinating sense of regional community. The struggle for autonomy for all Macedonian territories did not invalidate ethnic affiliations but revealed a prospective new niche. In the 19th century the term 'Bulgarian' was quite commonly used by the Orthodox Slavs inhabiting the territory of Macedonia. (P. Koledarow, 1985). It did not have, however, a national connotation widespread in Danube Bulgaria. At the same time during that period the name 'Bulgarian' was employed in parallel with the term 'Macedonian Slavs.' (J. Cvijić, 1906; K. Wrocławski, 1985; M. Boškovski, 2003). The term 'Macedonian Slavs' was adopted in academic circles as a result of two censuses - a Greek census conducted by C. Nikolaides in 1889 and a German one by K. Oestereich in 1905, which recorded Macedonia's ethnic composition (J. Budský, 2003), though both scholars attribute to the term slightly different meanings. 
Oestereich uses it to denote all Slavs from the territory of Macedonia, while Nikolaides additionally distinguishes Serbs and Bulgarians. These seemingly insignificant differences say a lot about the emerging ethnic differentiation among the Slavic peoples and provide an external context for internal manifestations of increasing diversification.

Meanwhile, the internal manifestations of ethnic differentiation among the Slavic inhabitants of Macedonia were due to decisions of a purely religious or territorial nature that initially (i.e. at the turn of the 19th and 20th centuries) came down to the choice between Slavia Orthodoxa and Slavia Balcanica.

Slavia Orthodoxa reflected the old, 19th century Slavophile-Russian influence. Slavia Balcanica revealed a bond with the region. The term 'Macedonian Slavs' as a sign of a germinating identity attempted to combine territorial and religious ties and paved the way for the slavisation of the term 'Macedonian.'

From the beginning of the 20th century these tendencies become apparent in statements delivered by representatives of the Macedonian diaspora in Russia, Bulgaria and Serbia. The national 'bible' of the Macedonian people was published in 1903 by Krste Misirkov under the title За македониките работи (On Macedonian Matters). In contemporary Macedonia it is considered, not without reason, to be a manifestation of Macedonian national awareness, a document belonging both to Slavia Balcanica and to Slavia Orthodoxa. Misirkov's views published in the press in the 1920's, (the Bulgarian period), are a specific elaboration of those ideas. The author of За македониките работи expresses Macedonian identity through an individual list of sites of memory which embrace the conviction about ancient roots of Macedonian culture. I use the term 'sites of memory' following Pierre Nora (Les lieux de mémoire), albeit with a certain qualification. ${ }^{1}$ For I do not adopt the typology proposed by Nora. I understand the notion as a definite space-time continuum which exists in the collective memory through a certain event or person inscribed in

\footnotetext{
1 The term "sites of memory" was introduced and popularized in Polish by Andrzej Szpociński in his article Kanon historyczny $(1983,4)$. By "sites of memory" Szpociński understands, similarly to Nora, not only the actual place but also the "events and characters from the past as well as artifacts". They are not, however, all events, characters and products of a past culture, but only those which "communicate two kinds of things: values and identity of a community." I take the term "sites of memory" to mean a space-time continuum beginning in the past and embracing events and actors of those events. This way a "site of memory" is for me primarily a space-time continuum. For the space-time continuum exists only through events and actors of those events. In the present paper all cited and analyzed "sites of memory" constitute a verbalization of the "values and common identity" of the Macedonian diaspora of the 1920's and 30's. All of them also confirm the primacy of the territorial understanding of the notion "sites of memory"; cf. also J. Sujecka, Tradycja jako wyznacznik tożsamości narodu (na przykładzie Macedończyków i Bułgarów) [in:] Z polskich studiów slawistycznych, series X, Warsaw 2002.
} 
it, or through a certain recurrent sequence of events together with their main actors. It is worth noticing that e.g. in Biblical times all places were named after events in order to retain in the name the very spiritual aspect of the event (rabbi Elijahu E. Dessler, Pożadaj prawdy 2003 (Strive for truth 1999). The offering of Isaac happened on the mountain called 'har-ha-Morija' which means "the Eternal is watching." The Moriah Mountain is the place which, in this case, is treated as a witness of the event (Unterman, 1994). The 'translatability' of every element of life into a 'place,' which was present in biblical times, allows for the understanding of the primary aspect of our relations with a certain territory, which for me is an additional argument in favour of the 'territorial' understanding of memory sites. The stealing of an ox is subject to punishment not only due to the lack of respect shown for somebody else's property, but also because 'my ox is my field.' The loss of an ox means the destruction of work put into the field (Pecaric, Rabbi Sacha, 2003).

In the article Македонска култура (Macedonian Culture) published in 1923 in Sofia in one of the Macedonian diaspora's journals ("Пирин"), all sites of memory enumerated by K. Misirkov fit in the notion-symbol 'Macedonia' and constitute a realisation of the slogan "integral Macedonia." Together with the Ohrid archdiocese there are the figures of St. Kliment and St. Naum. In the newly created canon of the Macedonian people King Marko appears alongside Tsar Samuil. And the picture is completed by the figures of St. Cyril and St. Methodius and, somewhat unexpectedly, by the city of Skopje.

The Ohrid archdiocese along with the figures of Cyril and Methodius, Kliment and Naum are carriers of religious memory. Tsar Samuil evokes the state tradition, while King Marko - the folk tradition which for Macedonia, as well as for Bulgaria and Serbia, and more generally for all the Balkan Slavs under the Turkish rule, played the role of a surrogate tradition. Whereas Skopje is appointed the administrative centre of "Bulgaria enslaved by the Byzantine Empire."

All sites of memory enumerated by Misirkov consequently refer to the territorial identity. St. Kliment and St. Naum, Tsar Samuil, the Ohrid archdiocese, and Skopje are in Vardar Macedonia, while St. Cyril and St. Methodius belong to Aegean Macedonia. Although according to popular oral tradition King Marko comes from Vardar Macedonia, his biography makes him part of the Pirin Macedonia space-time continuum. The saints, as well as Tsar Samuil and the half-mythical half-historic figure of King Marko, and finally the Ohrid archdiocese, territorially all belong to Macedonia. Skopje also remains within the boundaries of the region, however, contrary to the other sites, it was added as a sign of the emerging ethnos.

The explanatory context for this heterogeneous notion-site is provided in another article by Misirkov Народността на македонците (Nationality of 
the Macedonian People) published in Sofia, in the journal of the Macedonian diaspora "20 Юли," in the mid-20th century. In the article the two lexemes 'Bulgarian' and 'Macedonian' are not a simple pair of synonyms. Misirkov tries to endow both names with meanings that would render the notions semantically distant.

First, he defines Macedonians as greater Bulgarians than Bulgarians themselves in Bulgaria proper:

Но ето че се раздават викове на самите македонци: ние сме българи, повече българи от самите българи в България...2

Further Misirkov explains his own point of view expressing his disagreement with the Serbian identity forced on the Macedonians:

Вий сте могли да победите България, да и наложите каквито си щете договори, но с това не се изменя нашето убеждене, нашето съзнание, че ний не сме сърби, /.../ (Народността на македониите, "20 Юли" 1924, 5, р. 3) ${ }^{3}$

He argues that it is due precisely to the refusal to accept this Serbian identity that the Macedonians used to be called Bulgarians. Moreover, this is how they want to be called in the future:

/.../ до сега сме се казвали българи, тъй се казваме днес и така искаме да се казваме и в бъдеще. (Народността на македонците, “20 Юли” 5, р. 3) ${ }^{4}$

Apparently the author of За македониките работи reneges on his own statements from 1903 which affirmed Macedonian separatism. However, it seems so only at first glance since Misirkov's article ends with a definition of Macedonianness which in some way remains in opposition to the meanings proposed at the outset

Ние ще бъдем повече македонци, отколкото българи, но македонци с свое македоно-българско н а ц и о н а л н о самосъзнание, с свое историческо минало, с своя литературен език, общ с български, с свое македоно-българско н а ц и о н а л н о училище, с своя национална църква, в които националното и религиозното чувство на македонеца да не бъде оскърбявано от ликът и

2 K. Misirkov, Народността на македониците “20 Юли” № 5, 1924, p. 3. All citations come from the journals of the Macedonian diaspora published in Sofia in the early 1920s., namely “Илинден”, “20 Юли”, “Пирин”. All of them were edited by Arseni Jovkov (1882-1924), a Macedonian from Vardar Macedonia who settled in Sofia after the Ilinden uprising. The round brackets after citations in the text include: the title of the article, name of the journal, issue and year, and the pages. See in English translation: "And here come the cries of the Macedonians: we are Bulgarians, even greater Bulgarians than Bulgarians themselves in Bulgaria...".

3 See in English translation: "You managed to defeat Bulgaria and to impose on it your own agreements, but this way you will never change our conviction, our consciousness that we are not Serbs".

4 See in English translation: "We have hitherto been called Bulgarians, this is what we are called today and what we want to be called in future". 
духът на сръбските светци, като Свети Сава. (Народността на македонците, „20 Юли” 5, p.3)

This claim to being Macedonians rather than Bulgarians redirects Macedonian self-identification. It clearly separates what is "purely" Macedonian from what is Bulgarian-Macedonian. The carrier of Macedonianness deprived of any qualifiers is "the historic past" and the Orthodox Church, described as national, since it is defined in opposition to the Serbian Orthodox Church and to its hypostasis St. Sava. The literary language and the system of education are inscribed in the Bulgarian-Macedonian spacetime continuum. Misirkov published his article in a journal issued by the Macedonian diaspora, but one based in Sofia and not in independent Macedonia, which did not exist at the time. The Bulgarian context of the 1920 's, contrary to its Serbian equivalent of that period, gives the emigrants from Vardar Macedonia as well as those from Aegean Macedonia a certain freedom of speech but, evidently, with clearly defined limitations. These limitations become visible through closing down of the Diaspora-owned journals that published articles presenting views independent of the official Bulgarian policy.

Thus, Macedonian separatism as formulated by Misirkov is shaped by the past, basically understood here as tradition of the territory, and by consistent denials of the Serbianness of Vardar Macedonia.

The definition of the future, also territorially determined, allows for a multitude of ethnoses. The future also embraces the project of the "ido" language - a language that according to Misirkov's intentions should solve the Macedonian Question.

What should "Ido" be:

Идо би могъл да стане не само средство за общение с западните културни народи на стария и новия свят, но и за взаимно общение между всички македонски народности: българи, аромани, албанци, турци и гърци, като всеки македонец, освен майчиния си език, като средство за общуване с своите сънародници, изучава още и международния език „Идо” за общуване с другите народности в Македония и в целия културен свят. (Идо на македонците, „20 Юли” 1924,14, р. 2$)^{6}$

5 See in English translation: "We will be Macedonians rather than Bulgarians, but Macedonians with our own Macedonian-Bulgarian self-awareness, with our own historic past, with our own literary language (albeit) similar to Bulgarian, and our own Macedonian-Bulgarian school, our own national Orthodox Church in which national and religious feelings of no Macedonians would be offended by paintings and the spirit of Serbian saints, such as St. Sava".

6 See in English translation: "Ido could become not only a means of communicating with the West /.../, but also a tool for communication between all Macedonian nationalities: the Bulgarians, Aromanians (Vlachs), Albanians, Turks and Greeks. Every Macedonian, besides learning their own native language as a way of communicating with their countrymen, would also learn 
Misirkov's proposed that the "ido" language be a specific Macedonian variant of Esperanto - a language that would be on the one hand, an effective means of communicating with the West, and on the other, a tool for communication between all Macedonians.

The remarkable "ido" project confirms a strong sense of territorial identity, which Misirkov considered the foundation of all other projects for solving the Macedonian Question.

The gradually emerging ethnic identity may be defined on the one hand, by a negative stereotype of a Serb and on the other, by the arising distance from Bulgarians as traditional representatives of Macedonian interests on the international arena.

It is impossible not to notice that in Misirkov's fundamental work $3 a$ македониките работи, and contrarily to his articles dating from the 1920's, the Serbs were excluded from Macedonianness in its territorial sense. Misirkov's overt anti-Serbianness reflects disagreement with Serbian reluctance to recognise Macedonian desire for a distinct cultural identity.

Distance to the Bulgarians, on the other hand, corresponds to a changed perception of the distance between Skopje and Sofia. Their territorial unity dating from the period of the Ottoman Empire split in two space-times after the Second Balkan War and the outcome of World War I consolidated the boundary. Macedonia became for the Bulgarians a country of "stones and wild apples":

А за Македония мнозина „просветени” и пет пари не дават. Те не я и познават. За тях тя е страна с камъни и диви ябълки ... Ето защо българската опозиция не е опасна за сръбското владение на Македония. (Народността на македонците, “20 Юли”, 1924, 5, р.3)

Balkan wars and World War I, by erasing previous Macedonian-Bulgarian unity which existed under the Ottoman Empire, changed the order that had lasted for five hundred years and introduced a new one, in which Macedonia was relocated in Bulgarian consciousness to the sphere of myths.

Inversely, Bulgaria became one of the focal points in Macedonian mentality. A conviction that the "enlightened" Bulgarians started to consider Macedonia as provincial determined the horizon of Misirkov's prospective projects.

Additional context was created by an ongoing discussion in the press representing the Macedonian Diaspora in Sofia. There, the program of emancipation of the Macedonian Question was articulated in greater detail.

the international Ido language that would allow them to communicate with other nations inhabiting Macedonia as well as the entire civilised world".

7 See in English translation: "And for Macedonia most of the so-called "enlightened" Bulgarians would not even give a thing. They do not even know it. For them it is a country of stones and wild apples... This is why Bulgarian opposition does not pose a threat to Serbian domination in Macedonia." 


\section{Macedonia - site of collective memory}

Krste Misirkov's projects, published in the first half of the 1920's in journals edited by Arsenii Jovkov, aimed at solving the Macedonian problem combining the sense of territorial and ethnic identity.

The idea of making Europe interested in creating a Balkan buffer state, an equivalent of Switzerland, originates from the same incentives that a little earlier pushed Misirkov to present the project of the "ido" language. For both, Macedonia as Switzerland of the Balkans and the "ido" language, appeal to the Macedonians' sense of a territorial bond:

Само чрез обединението на всички македонци вътре в трите Македонии и чрез онова на всичката македонска емиграция в четирите съседни балкански столици и в Америка с една обща програма за създаването от Македоня една балканска Швейцария, дето всяка община ще се ползува с свобода на национално и верско самоопределение, ще се дойде до краят на балканското, общоевропейското съперничество за хегемония на Балканите. (Изходът “Пирин”, 1923, 8, p. 1) ${ }^{8}$

For Misirkov, just like for A. Jovkov, united Macedonia is a value in itself. Therefore, the task determining the scope of Misirkov's projects is to find a political structure for the mythologem целокупна Македонија (integral Macedonia). According to Misirkov such political structure would be multiethnic and multi-faith. A Macedonia insulated from insidious designs of its neighbours. In his opinion, this view of Macedonia may once and for all put an end to the eternal competition for hegemony and close the perpetually returning Eastern issue.

"Integral Macedonia" is a mythologem which de facto confirms the regional bond and hence affirms Macedonian separatism.

\section{Conclusions}

The sense of territorial identity gains force whenever political means of solving the Macedonian Question, a repugnant legacy of the Eastern issue, become scarce. This attitude is reflected in the articles published by the representatives of the Macedonian diaspora in journals of its different centres. Due to space constraints I decided to present only (and at least) the views of Krste Misirkov, a very complex figure indeed, who in contemporary

\footnotetext{
8 See in English translation: Only by uniting all Macedonians in all three Macedonias (Vardar, Aegean, and Pirin - J.S.), and all Macedonian emigrants in the four neighbouring Balkan capitals and in America in a common project of Macedonia as a Balkan Switzerland, whereby every [national] group could exercise the freedom of national and religious self-identification, the BalkanEuropean competition for hegemony in the Balkans may come to an end.
} 
Macedonia belongs to the undisputable national pantheon. His opinions on the Macedonian Question were far from explicit and his statements delivered at different stages of his life do not fit into a cohesive whole as the national purists would want it. However, it is difficult to imagine a better mirror for "Macedonian matters" in the 20th century and a more comprehensive picture of the twisted paths that the Macedonian Slavs took to reach the concept of 'Macedonian' understood as an ethnos, not only in its territorial aspect.

A bond with the territory has never disappeared from Macedonian selfperception. Only the constant presence of territorial identity explains the assimilation of the ancient heritage, which is in fact heritage of a territory, into the Macedonian national canon. It is further confirmed by the most recent Macedonian history textbooks for high school students where the ancient tradition is treated as a part of their own heritage

While the bond with the territory is still an integral part of the Macedonian elite's consciousness, the question of double identity remains less obvious. In Misirkov's time double identity, expressed through various ethnic configurations, on the one hand shaped Macedonian self-identity and on the other proved the distinctiveness of a 'Macedonian' at that time (i.e. in the first half of the 20th century) from a 'Serb' in Serbia proper and a 'Bulgarian' in Bulgaria proper, thus creating favourable conditions for the emergence of separatist understanding of Macedonianness, allowing even non-Slavs to be Macedonians. Macedonianness began to be founded on Slavicness relatively late and this dependence was propagated quite naturally mainly by Slavophile circles (the circle of Nace Dimov) and by the communists in the 1920's and 1930's (J. Sujecka, 2001). However, in the first half of the 20th century there still existed alternatives, such as, for instance, the above-described project of Krste Misirkov. The most evident connection between the term 'Macedonian' and Slavicness crystallised in Tito's post-war Macedonia, de facto undermining the notion of double identity in the sense in which it had functioned in the first half of the 20th century.

Мисирков К.

\section{References}

Texts

(1903) За македониките работи. Софя. Конески, Блаже, Димитровски, Тодор (eds.), Јубилејно издание по повод стогодишнината от раг'ането на авторот, Skopje 1974.

(1923) Македонска култура “Пирин”, 2, pp. 2.

(1923) Изходът "Пирин”, 8, рр.1.

(1924) Народността на македониите “20 Юли”, 5, рр. 3.

(1924) Идо за македонцичте “20 Юли”, 14, pp. 2. 
Бошковски М.

\section{Other References}

(2003) Имината на Македонија и Македониите во средновековните извори. Скопје.

Budský J.

(1998) Etnická skladba osmanské Makedonie v období let 1878 - 1913. Společenský a kulturní rozvoj jednotlivých, předevšim neslovanských národností na makedonském území, in: „Slovanské Historické Studie” 24, Praha, pp. 311-372.

Цвијић Ј.

(1906) Проматрана о етнографји македонских словена (друго попуюено издане), Београд.

Dessler rabi Elijahu E.

Pożądajprawdy. Esejeo księgach Wajikra, Bamidbari Dewarimorazrozważania o wolnej woli. Kraków 2003.

Kłoskowska A.

(1993) Wielokulturowość regionów pogranicza [in:] Handke Kwiryna (ed.) Region, regionalizm - pojęcia i rzeczywistość. Warszawa, pp. 97-104.

(1997) Kresy - od pojęcia zamkniętego do otwartego sasiedztwa [in:] Handke Kwiryna (ed.), Kresy - pojęcie i rzeczywistość. Warszawa, pp. 229-238.

Коледаров П.

(1985) Името Македония в историческа география. София.

Melchior M.

(1990) Społeczna tożsamość jednostki. Warszawa.

Ристовски Б.

(2000) Крсте Мисирков нови истражувана и сознанија, Скопје.

(2001) Македонска нација во историја и во современостта (кон македонскобугарскитенедоразбирағьа) [in:] Ристовски Блаже, Столетија на македонската совест. Скопје, рр. 73-79.

Smith A. D.

(1999) Myths and Memories of the Nation. Oxford University Press.

(2004) The Antiquity of Nations. Cambridge.

Stawowy-Kawka I.

(2000) Historia Macedonii, Wrocław.

Sujecka J.

(2001) Pojęcie Macedonii w wybranych dokumentach, publicystyce i tekstach folkloru $z$ pierwszej połowy XX wieku. Od idei słowiańskiej jedności do federacji Batkańskiej. [in:] Korytkowska Małgorzata, Darasz Zdzisław, Minczew Georgi (eds.) Między kultura "niska" a "wysoka". Pamięci Profesor Teresy Dąbek-Wirgowej. Materiały z Konferencji Naukowej Łódź 28-29 marca 2000. Łódź, pp. 133-140.

(2003) Tradycja jako wyznacznik tożsamości narodu (na przykładzie Macedończyków i Bułgarów) [in:] Suchanek Lucjan (ed.) Z polskich studiów slawistycznych, seria $X$, Warszawa, pp. 187-192. 
Szacka B.

(1987) Przestrzeń i czas - dwa wymiary obrazu Polski [in:] Szacka Barbara, Polska dziecięca. Warszawa, pp. 237-292.

Szpociński A.

(1983) Kanon historyczny, [in:] „Studia Socjologiczne”, 4(91), pp. 129-146.

Wat A.

(1986) Dziennik bez samogłosek. [in:] Rutkowski Krzysztof (ed.) Pisma wybrane, t. 2 Londyn.

Wrocławski K.

(1985) Stosunki ethniczne na Bałkanach ws świetle Kronik Macieja Stryjkowskiego, [in:] „Balcanica Posnaniensia II.” UAM. Poznań, pp. 265-273.

\section{Ciągłość i jej brak. Kwestia terytorializmu i podwójnej tożsamości z perspektywy macedońskiej}

Poczucie tożsamości terytorialnej odzywa się ze szczególną siłą w sytuacjach, kiedy wyczerpują się polityczne możliwości rozwiązania problemu macedońskiego, jako niedobrego spadku po kwestii wschodniej. Potwierdzają to wypowiedzi przedstawicieli macedońskiej diaspory publikowane na łamach czasopism, wychodzących w różnych miejscach jej skupisk. Zdecydowałam się na przedstawienie jedynie (i aż) poglądów Krste Misirkova, należącego w dzisiejszej Macedonii do niekwestionowanego panteonu narodowego, $\mathrm{w}$ istocie postaci wielce skomplikowanej. Jego poglądy w kwestii macedońskiej były dalekie od jednoznaczności, a wypowiedzi wygłaszane na różnych etapach życia nie układają się w całość, jakiej chcieliby narodowi puryści, natomiast trudno sobie wyobrazić lepsze zwierciadło „spraw macedońskich” w XX wieku i pełniejszy obraz krętych dróg, jakimi macedońscy Słowianie dochodzili do pojęcia „Macedończyk" rozumianego jako éthnie (A. D. Smith, 2004) a nie tylko terytorialnie.

Więź z terytorium nigdy nie zniknęła z macedońskiego myślenia o sobie samych. Jedynie stałą obecnością tożsamości terytorialnej można wytłumaczyć asymilację dziedzictwa antycznego, czyli faktycznie dziedzictwa terytorium, do macedońskiego kanonu narodowego. Potwierdzają to najnowsze macedońskie podręczniki do nauki historii dla szkół średnich, w których tradycja antyczna jest traktowana jako część tradycji własnej.

O ile jednak więź z terytorium jest nadal integralną częścią świadomości macedońskich elit, to zupełnie inaczej wygląda kwestia podwójnej tożsamości. W czasach Misirkova podwójna tożsamość, wyrażająca się poprzez różne etniczne konfiguracje, z jednej strony kształtowała macedońską tożsamość własną, z drugiej zaś to dzięki niej pojęcie „Macedończyk” w tym czasie (tzn. w pierwszej połowie wieku XX) potwierdzało swoją odrębność od Serba z Serbii właściwej i od Bułgara 
z Bułgarii właściwej i tym samym sprzyjało kształtowaniu się separatystycznego rozumienia macedońskości. Ten sposób widzenia umożliwiał bycie Macedończykiem także nie-Słowianom. Oparcie pojęcia macedońskości o słowiańskość nastąpiło stosunkowo późno i było propagowane w sposób naturalny głównie przez środowiska słowianofilskie (petersburski krąg Nace Dimova), ale w latach dwudziestych i trzydziestych XX w. także przez środowiska komunistyczne (J. Sujecka, 2001). Jednak w pierwszej połowie XX wieku miało wciąż alternatywne propozycje, jak chociażby omówiony przeze mnie projekt K. Misirkova. Najwyrazistsze powiązanie pojęcia „Macedończyk" ze słowiańskością nastąpiło w powojennej Macedonii czasów Josipa Broz Tity i w istocie podważyło pojęcie podwójnej tożsamości, w tym sensie w jakim funkcjonowała ona w okresie wcześniejszym, tzn. w pierwszej połowie wieku XX. 